\title{
Business Negotiation Approach Model and Strategy for Community Leaders in Resolving Land Dispute Conflicts in Maluku Province
}

\author{
Fransiska Natalia Ralahallo $^{1)}$, Aris Firmansyah ${ }^{2)}$ \\ 1), 2) Faculty of Economic and Business, Universitas Pattimura, Ambon, Indonesia \\ Email:fralahallo@yahoo.co.id ${ }^{l}$,_ArisFirmansyah@upi.edu ${ }^{2}$
}

\begin{abstract}
This study was written with the aim of knowing and describing how the Model Approach and Negotiation Strategy of Community Leaders in Resolving Land Dispute Conflicts in Marafenfen Village, Aru Islands, Maluku Province Community leaders are parties who have advantages over the general public and play an important role in making decisions. Land dispute conflicts that occurred in the village of Marafenfen are social conflicts that often occur considering the people who do not really understand the rights to the land they want to own. This article is an article that uses a qualitative descriptive method, namely research that seeks to describe or describe the object under study based on the facts in the field. then the data analysis technique used in this study is qualitative data analysis, The results of the research obtained by the author can be concluded that in resolving land disputes, community leaders use Competitive Approach Model but some community leaders do not understand the Negotiation processes so they still have not found an agreement.
\end{abstract}

Keywords: negotiation approach model, negotiation strategy, land dispute conflict, business negotiation

\section{Introduction}

In Indonesia lately, there have been many conflicts, both horizontal conflicts, and vertical conflicts. Horizontal conflicts occur between groups in society, which are distinguished by religion, ethnicity, nation, and others. While vertical conflicts often occur between certain community groups or the lower class of society with the upper class or dominant society. Even today, social conflicts continue to occur over and over again from one place to another in various forms throughout Indonesia. Conflicts occur every year, one of which is a conflict over land disputes. Earth is a gift from God Almighty for mankind on earth. And Land is a basic need for people. From birth to death, humans need land to have a place to live and a source of life. Cosmologically, the land is a place where humans live, work, and live, where they come from and where they will go.

Marafenfen Village is one of the villages in the South Aru sub-district, Aru Islands Regency, Maluku Province. Marafenfen Village is opposite to Doka Village which is also one of the villages in the South Aru sub-district. With the dominance of savanna and swamp areas, and surrounded by rivers, the area is an area that has an important role as a habitat for various animals, some of which are endemic only in Aru, such as Pigs, Deer, Swallows, Yellow Crested Cockatoos, Cendrawasih, and others make, for this reason, many of the residents' livelihoods are farmers, planters, and hunting.

In November 2021, there was a conflict between the Marafenfen Village Community and the local Regency Government due to a land dispute that was planned to be built for the Navy airport and various other facilities, in which the local indigenous community filed a lawsuit for unilateral land release (Belseran, 2021). Which until now has not reached an agreement.

The output of this research is to find out and describe the Approach Model and Negotiation 
strategy of community leaders in resolving land disputes. only focuses on resolving organizational conflicts, business cooperation, business disputes (Prawira, 2019; Hamdan, Ratnasari, \& Hirzi, 2015; Haerani, 2020).

\section{Literature Review}

\subsection{Definition of Negotiation}

Negotiation comes from English negotiation which means negotiation. According to (Endarmoko, PT. Gramedia Pustaka Utama), in the Indonesian Thesaurus it says what is meant by negotiation, namely: first, the process of bargaining by negotiating in order to reach a mutual agreement between one party (group or organization) and another party (group or organization). On the other hand, each of these parties has the same interests, but they have different target needs and motivations. That's why they negotiated to reach an agreement. Second, both parties feel that they will benefit from peaceful dispute resolution through negotiations between the disputing parties.

According to Scott (2005), negotiation is a form of a meeting between two parties, namely us and the other party, the goal of the negotiation is to reach an agreement. It is more clear that negotiation is a process of speaking skills between two parties, each of whom has their own goals and points of view, trying to reach an agreement that satisfies both parties on the same issue. A negotiation is a form of interpersonal speaking skills. The process of speaking skills, both verbal and nonverbal, is important to achieve the goals of negotiation and resolve conflicts. an agreement of both parties (Ati, 2015).

\subsection{Cooperative Approach Model}

This approach model is also known as the Shared Problem Solving Model or the Win-Win Model; According to Schoonmaker (1993). Win-Win Negotiation is feasible if the issue being negotiated concerns mutual interests. There is mutual trust between the negotiating parties. Therefore, the action suggested by Thorn what needs to be done in win-win negotiations are (Mufid, 1997)

1. Ensuring that the other party chooses a win-win model (rather than wanting to win alone);

2. Identify the problem at hand (do not discuss the solution before recognizing the problem);

3. Deal with problems that have the potential to have win-win solutions;

4. Sharing information with each other;

5. Give positive signs to other parties such as giving gifts;

6. Avoid defensiveness and give consent if the climate is appropriate;

7. Avoid as much as possible a legalistic approach.

Win-win or win-win negotiations are a negotiation model that has a higher chance of success than win-lose or win-lose negotiations. The victory achieved is a collective victory. The resulting solution is related to a mutually beneficial center of gravity, which is not based on the position of either party.

\subsection{Competitive Approach Model}

This model is often also referred to as a win-lose approach model or Win-Lose Model. According to Thorn quoted by (Mufid, 1997), to win a win-lose negotiation model, you must 
take 4 (four) steps:

1. Clearly define our commitment to what we want.

2. Shows the consequences that will occur if the desire is not achieved.

3. Blocking the opponent to achieve his wishes.

4. Shows a way out that can save the opponent's face by offering consolation concessions.

This Win Lose or Win-Lose model does not always take the form of violence such as the destruction of facilities, war, and other violence. This model also allows a negotiator to invite other people to be friends (community, country, etc.), but shows the attitude that the negotiator positions the negotiating partner as an enemy or ruler.

\subsection{Business Negotiation Strategy}

According to Uchjana (2003:300) Strategy is essentially planning and management to achieve a goal. But to achieve this goal, the strategy does not function as a road map that only shows the direction, but must show the operational tactics.

Negotiation strategies according to Purwanto \& Lantang (2014) in his book (Business communication, conceptual and cultural perspectives) are:

1. Win - Lose (lose-win) in the sense of a form of negotiation with the assumption that only one party will benefit from the negotiated interests.

2. Win-win solution (Win-Win) is a form of negotiation in which all negotiating parties are expected to benefit by prioritizing compromise.

3. Compromise is a compromise in the sense that decisions are made on the basis of deliberation, not defeat (win or lose).

\subsection{Conflict}

According to Kilman and Thomas (1978), conflict is a condition of incompatibility between values or goals to be achieved, both within the individual and in relation to other people. The conditions that have been stated can interfere with and even hinder the achievement of emotions or stress that affect work efficiency and productivity (Wijono, 1993: p.4). According to Wood, Walace, Zeffane, Schermerhom, Hunt and Osbon (1998:580) what is meant by conflict (within the scope of the organization) is: "Conflict is a situation which two or more people disagree over the issue of organizational sustainability and/or experience some emotional antagonism with one other ". This more or less means that conflict is a situation where two or many people disagree on an issue that concerns the interests of the organization and/or with feelings of hostility towards one another. According to Stoner, organizational conflict includes disagreements about the allocation of scarce resources or disputes about goals, status, values, perceptions, or personality (Wahyudi, 2006: 17). Meanwhile, Daniel Webster defines conflict as 1. Competition or opposition between parties that are not compatible with each other. 2. Conflicting circumstances or behavior (Pickering, 2001).

\subsection{Land Dispute}

According to (Murad, 1991) the notion of land disputes or can also be said as disputes over land rights, namely the emergence of legal disputes that originate from complaints from a party (person or entity) containing objections and claims for land rights, both on land status, priorities, and rights. In essence, a land case is a conflict of interest in the land sector between 
who and whom, for example, concrete between individuals and individuals, individuals and legal entities, legal entities, and entities. law and so on. In connection with the foregoing, in order to provide legal certainty as mandated by the basic agrarian law, the response/reaction/settlement to the land case concerned, among others, can be given to the interested parties (community and government Business Community Leaders in Marafenfen Village, Aru Islands Regency, Maluku Province

\section{Research Method}

This type of research uses descriptive qualitative research. According to Sugiyono (2016) suggests that qualitative research is research that is used to analyze data by describing or describing data that has been collected as it is without the intention of making generalized conclusions or generalizations.

To get the relevant results from the following research, the authors set a limit on the object to be studied, namely community leaders who are in Marafenfen Village, Aru Islands Regency, Maluku Province which will be the object of research.

As the object of this research is a village with the following characteristics:

1. It is a village that is in conflict with land disputes

2. Community leaders do not yet have knowledge of strategic approaches in negotiations

Based on these characteristics, the writer chose Marafenfen Village as the object of the following research. While the subject to be studied is the Negotiation Approach Method and Negotiation Strategy

\section{Findings and Discussions}

Approach model and strategy Negotiation of community leaders in resolving land dispute conflicts If viewed from the existing data through the news, there are efforts by community leaders to reconcile the wishes of the disputing parties to reach agreement and settlement in the case of land disputes that occurred in the village of Marafenfen. What has been seen is the way of bringing together the wishes of the disputing parties to reach an agreement and resolve land disputes based on consensus deliberation to reconcile the path of peace (Belseran, 2021).

This meeting was held at the office of the regent of the Aru Islands which was attended by all groups of people as well as parties in dispute in the case of land disputes. However, community leaders do not have broad insight regarding the Negotiation Strategy in resolving land conflicts. Community leaders are able to resolve land disputes that occur in Marafenfen village. in this case, the community leaders only act as conciliators. Community leaders in this regard and have full responsibility to help cases of land conflicts that occur. In the resolution of the land conflict in the first case, the solution through conciliation by community leaders was found a settlement point based on consensus deliberation held at the Aru Islands Regent's office, in this case, the land that became the conflict was distributed to the parties who sued based on authentic evidence provided (Yanuarti, 2010).

Semmy Waelerunny said after the Navy wrote a reply to Komnasham, with the help of Governor Marc and Maluku lands, he discovered the navy's crimes there. We sued Governor Soekoso Marc, and if later there is a process that is submitted to the parties, we have paid court fees and registered according to the applicable regulations, so that is not our authority anymore. Semuel Waileruny, a lawyer from the village of Malafenfen, argued that the judge's decision was unfair. The judge at the trial was believed to have largely ignored the evidence presented in the form of statements and statements that the community was not involved in the land acquisition process, but their names were confiscated by the Indonesian Navy. All the 
evidence submitted by the indigenous peoples through the judge's lawyer Semuel Waileruny was considered weak. As a result of this refusal, hundreds of hectares of shared land eventually fell into the hands of the Indonesian Navy. Rar Gwamar Airport and Dobo Harbor were blocked by the traditional elders of Ursia and Urlima, Marafenfen Village, Aru Islands Regency, Maluku. the decision on the dispute over the customary land of Aru and the Navy at the Dobo District Court covering an area of 689 hectares was rejected by the panel of judges at the Dobo District Court. According to news from (CNN Indonesia, 2021)

\section{References}

Belseran, C. (2021). Masyarakat Adat Marafenfen Terusik Kehadiran TNI-AL. Ambon: Situs Berita Lingkungan (Mongabay).

CNN Indonesia. (2021, November 17). Tetua Adat Blokir Bandara Dobo Maluku Usai Vonis Sengketa Lahan TNI AL. Retrieved from CNN Indonesia: https://www.cnnindonesia.com/nasional/20211117195346-20-722647/tetua-adat-blokirbandara-dobo-maluku-usai-vonis-sengketa-lahan-tni-al Endarmoko, E. ( PT. Gramedia Pustaka Utama). Tesaurus Bahasa Indonesia, Edisi Tiga. Jakarta: 2006.

Haerani, R. (2020). Tinjauan Yuridis Perjanjian Perdamaian Dalam Penyelesaian Sengketa di Pengadilan Melalui Proses Negosiasi. Jurnal Unizar Law Review, 3(1).

Hamdan, Y., Ratnasari, A., \& Hirzi, A. T. (2015). Kemampuan Negosiasi Pengusaha dalam Meningkatkan Kesepakatan Bisnis. MIMBAR Vol 31, 21-30.

Mufid, A. B. (1997). Negoisasi untuk Mencapai Kesepakatan. Jakarta: Badan Diklat Depdagri.

Murad, R. (1991). Penyelesaian Sengketa Hukum Atas Tanah. Bandung: Alumni.

Prawira, A. M. (2019). Strategi Negoisasi untuk mengendalikan konflik organisasi (Studi Pustaka). AM Prawira.

Purwanto, \& Lantang. (2014). Komunikasi Bisnis ,Perspektif Konseptual Dan Kultural . In Purwanto, \& Lantang, Komunikasi Bisnis ,Perspektif Konseptual Dan Kultural (p. 256). Yogyakaryta: Pustaka Belajar.

Schoonmaker, A. (1993). Langkah-langkah Memenangkan Negoisasi. Jakarta: PIM.

Scott, B. (2005). The Skills of Negotiating, Jaico Publishing House. Mumbai.

Sugiyono. (2016). Metode Penelitian Kuantitatif, Kualitatif dan R\&D. Bandung: PT Alfabet. Yanuarti, C. (2010). Konstruksi Hukum Penyelesaian Sengketa Tanah Hak Milik Nomor 158 dan Nomor 806 di Kelurahan Keprabon Surakarta. Surakarta. 